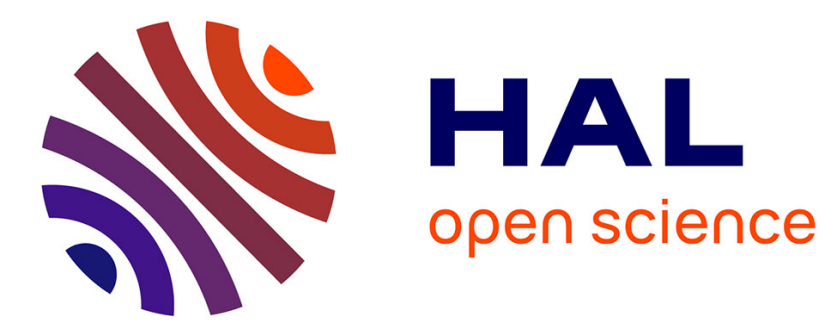

\title{
Very long-term incision dynamics of big rivers
}

\author{
Jean-Louis Grimaud, Dominique Chardon, Anicet Beauvais
}

\section{To cite this version:}

Jean-Louis Grimaud, Dominique Chardon, Anicet Beauvais. Very long-term incision dynamics of big rivers. Earth and Planetary Science Letters, 2014, 405, pp.74 - 84. 10.1016/j.epsl.2014.08.021. hal-01097322

\section{HAL Id: hal-01097322 \\ https://hal.science/hal-01097322}

Submitted on 23 Dec 2016

HAL is a multi-disciplinary open access archive for the deposit and dissemination of scientific research documents, whether they are published or not. The documents may come from teaching and research institutions in France or abroad, or from public or private research centers.
L'archive ouverte pluridisciplinaire HAL, est destinée au dépôt et à la diffusion de documents scientifiques de niveau recherche, publiés ou non, émanant des établissements d'enseignement et de recherche français ou étrangers, des laboratoires publics ou privés. 


\section{Very long-term incision dynamics of big rivers}

3

4

\section{5}

$$
\text { Jean-Louis Grimaud }^{1,2,3,4 *} \text {, Dominique Chardon }{ }^{1,2,3} \text {, Anicet Beauvais }{ }^{5}
$$

\author{
${ }^{1}$ Université de Toulouse, UPS (OMP), GET, \\ 14 avenue Edouard Belin, 31400 Toulouse, France \\ ${ }^{2}$ CNRS, GET, 31400 Toulouse, France \\ ${ }^{3}$ IRD, UR 234, GET, 31400 Toulouse, France \\ ${ }^{4}$ now at St. Anthony Falls Laboratory, \\ University of Minnesota, Minneapolis, Minnesota, USA \\ ${ }^{5}$ Aix Marseille Université, IRD, CNRS, CEREGE UM 34 \\ BP 80 - 13545 Aix-en-Provence Cedex 4, France
}

Manuscript EPSL-D-14-00446

Submitted 24 April 2014

Revised 24 July 2014

\section{*Corresponding author:}

E-mail address: jgrimaud@umn.edu

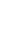


34 Constraining large-scale incision dynamics of shield and post-rift margin

35 domains is key to understanding the sediment routing system over the overwhelming

36 part of the continental surface. Based on dated and regionally correlated incision

37 markers from West Africa, we reconstruct for the first time the entire paleo-long

38 profiles of big rivers such as the Niger at ca. 24, 11 and $6 \mathrm{Ma}$, as well as the Eocene

39 topography those rivers have dissected. The results provide boundary conditions and

40 calibration for surface process models and paleodrainage dynamics. Though spatially

41 and temporally variable, incision remained mostly below $10 \mathrm{~m} / \mathrm{my}$ with a mean around

$425 \mathrm{~m} / \mathrm{my}$. The spatial stability of both the river outlets and divides imposed maintenance

43 or increasing concavity of the river long profiles through time, resulting from spatially

44 contrasted adjustment of river segments bounded by recurrent lithogenic knickzones

45 that persisted since $24 \mathrm{Ma}$. Drainages evolved preferentially by very slow slope

46 decrease or uniform incision in between the stationary knickzones of evolving

47 amplitude, with apparently no relation to base level change. Therefore, knickzone height

48 or position may not simply reflect the transient response of big rivers to base level fall

49 as predicted by stream-power incision river models. This may also challenge uplift

50 histories of deep continental interiors retrieved from river long profiles inversion relying

51 on such models. Very slow incision allowed amplification of the Hoggar hot spot swell

52 and flexural uplift of the continental margin to be recorded by river long profiles,

53 emphasizing the potential of big non-orogenic rivers as gauges of dynamic topography.

55 1. Introduction

56 Quantifying incision dynamics of large drainage basins over geological time

57 scales is relevant to constraining long-term landform evolution processes and the 
responses of the sediment routing system to lithospheric deformation and climate change. Spatial and temporal variations in incision rates are mostly investigated through the study of longitudinal profiles of rivers as gauges of transient responses of landscapes to perturbations such as base level fall due to uplift. Such responses are modeled using stream-power equations and commonly integrate the formation and headward propagation of knickpoints as a mechanism of river long profile evolution (e.g., Whipple and Tucker, 1999; Crosby and Whipple, 2006; Jeffery et al., 2013). Based on such models, an inversion procedure of river long profiles has been implemented to estimate surface uplift magnitudes (Roberts and White, 2010; Paul et al., 2014). But studies of incision processes are mostly based on modeling and/or focus on active tectonic settings over short time scales $\left(10^{3}-10^{6} \mathrm{yr}\right)$ and face a crucial lack of regional markers of past base levels that would allow calibrating or testing incision models on Pre-Quaternary geological time scales $\left(10^{6}-10^{8} \mathrm{yr}\right)$. This is particularly exemplified in non-orogenic settings where erosion is so slow that it may rarely be detectable by lowtemperature thermochronology methods over the Cenozoic (e.g., Beauvais and Chardon, 2013). Constraining large-scale incision dynamics in such settings is however key to understanding the long-term reactivity of the overwhelming part of the continental surface that supplied most of the world's passive margins and intracratonic sedimentary basins. In these tectonically "stable" contexts, river long profiles display series of major knickzones and are commonly convex downstream (Summerfield, 1991, 1996;

78 Pazzaglia et al., 1998). These profiles pose the sizable challenge of knowing how and 79 how fast their geometry has been acquired, how knickzones formed and evolved and 80 what caused their convexities. If post-rift flexure of passive margins has been suggested 81 as a cause of warping of downstream river segments (Gilchrist and Summerfield, 1990), 82 the contributions of climatically induced sea level or erosion process changes and 
83 lithospheric deformation to the acquisition of non-orogenic river long profiles are still

unclear (Summerfield, 1991; Schumm, 1993; Beauvais and Chardon, 2013).

For the first time, we reconstruct consecutive long profiles of big rivers over their entire length since the Eocene by using the exceptional geomorphic record of successive incision stages of the West African subregion. Successive paleoprofiles allow constraining evolving rivers shapes with an emphasis on the dynamics of knickzones and are used to calibrate large-scale patterns of incision rates for three time slices over the last $24 \mathrm{Ma}$. Anomalies in river profiles are also analyzed as proxies of long wavelength lithospheric deformation.

\section{Geomorphic setting and incision chronology}

West African drainage is organized mostly around the Guinean rise and the Hoggar and Jos topographic massifs (Figure 1a). The drainage of West Africa is governed by three major river systems: the Senegal, Volta and Niger and includes shorter rivers draining the seaward slope of the Guinean rise (Figure 1a). The river long profiles are characterized by long (> $50 \mathrm{~km}$ ), low gradient sections (i.e., 0.1 to $2 \%$ o) separated by knickpoints, identified as short $(<30 \mathrm{~km})$ reaches of steep gradient $(>1 \%$; Figure 1b). Two major regional knickzones made of a series of knickpoints over $>50$ $\mathrm{km}$ long river segments are recognized on most river profiles at ca. 50-100 m and 200$250 \mathrm{~m}$ elevation (Figures 1a and $1 \mathrm{~b}$ ).

West Africa is characterized by an exceptional sequence of stepped lateritic paleolandsurfaces (Figure 2), whose remnants are preserved throughout the subregion. Paleo-river long profiles were constructed by using the remnants of these paleolandsurfaces along the studied rivers (see below). In the following, the characteristics of the paleolandsurfaces are summarized after the works, among others, 
108 of Vogt (1959), Eschenbrenner and Grandin (1970), Burke and Durotoye (1971),

109 Michel (1973), Grandin (1976), Boulangé et al. (1973), Boulangé and Millot (1988) and

110 the syntheses of Beauvais et al. (2008), Burke and Gunnell (2008) and Beauvais and

111 Chardon (2013).

Relicts of surface 1 are preserved on West African summits and numerous

113 mesas. It is a low-relief surface, which is the end product of enhanced chemical

114 weathering that started in the Late Cretaceous and culminated in the Early Eocene to

115 form bauxites (Figure 2). This bauxite-capped Eocene landscape, also called hereafter

116 the bauxitic surface, represents today's envelope of the West African topography. The

117 following paleolandsurfaces are stepped below the bauxite remnants and mark

118 successive incision stages of the bauxitic surface (Figure 2). Surface 2, the so-called

119 Intermediate surface, characterizes a differentiated remnant landscape coated by a thick

120 ferricrete sealing an in-situ formed weathering mantle (Figure 2). As opposed to

121 surfaces 1 and 2, the following three paleolandsurfaces in the sequence are pediments

122 (glacis in the French literature): the so-called high (surface 3), middle (surface 4) and

123 low glacis (Figure 2). The glacis surfaces commonly carry reworked bedrock and

124 lateritic fragments derived from surfaces 1 and 2 and were, together with their cover,

125 weathered to various degrees. Because the low glacis did not develop uniformly

126 throughout West Africa or is commonly connected to local base levels, it was not used

127 for paleo-long profiles reconstructions. Consequently, "surface 5" was considered as the

128 current river levels (Figure 2). Each paleolandsurface (1 to 5) is taken as the end product

129 of an incision period (I to V, respectively; Figure 2). Our study focuses on incision

130 periods III to $\mathrm{V}$ and allows visualizing the amount of dissection of the Eocene

131 topography during erosion period II. 
Age constraints on the shaping, weathering and abandonment of the successive

133 paleosurfaces in the West African sequence were obtained from radiometric ${ }^{39} \mathrm{Ar}-{ }^{40} \mathrm{Ar}$

134 dating of supergene K-Mn oxides (i.e., cryptomelane) in the weathering profiles of each

135 paleosurface from the Tambao type locality (Figure 1a) in Burkina Faso (synthesis in

136 Beauvais and Chardon, 2013). Surface and core samples were taken at various

137 elevations and depths spanning the altitudinal range of the paleolandsurfaces (Hénocque

138 et al., 1998; Colin et al., 2005; Beauvais et al., 2008). Paleosurfaces 1 to 4 yielded ${ }^{39} \mathrm{Ar}-$

$139{ }^{40} \mathrm{Ar}$ age groups of 59 - 45, 29 - 24, 18 -11 and 7-6 Ma, respectively, the Oligocene and

140 Mid-Miocene weathering periods being also recorded by Ar-Ar dates of supergene

141 jarosite and alunite in Southern Mali weathering profiles (Vasconcelos et al., 1994). The

142 lower limits of the radiometric age groups date the stabilization of the weathering front

143 established by the end of chemical weathering periods that ultimately led to duricrusting

144 of each paleosurface in connection with their local base level (Beauvais and Chardon,

145 2013). Therefore, ca. 45, 24, 11 and $6 \mathrm{Ma}$ are interpreted as the maximum age of

146 abandonment of each paleosurface by river incision due to climate switches from humid

147 to seasonally dry (Beauvais and Chardon, 2013; Figure 2a). In other words, the ages of

148 ca. 45, 24, 11 and 6 Ma are the terminal ages of paleosurfaces 1, 2, 3 and 4 respectively

149 (Figure 2a) bracketing the incision periods separating those paleosurfaces.

151 3. Method

152 We construct rivers paleo-long profiles based on the identification and mapping

153 of remnant of paleolandsurfaces S1 to S4 along the rivers courses over approximately

$15420 \mathrm{~km}$-wide corridors. This protocol is motivated by the fact that surfaces 2 and younger

155 systematically dip towards those rivers (e.g., Figure 3). Our database of remnant

156 lateritic paleosurfaces is that of Beauvais and Chardon (2013), which was extended to 
encompass the selected river corridors at about 400 stations. At each station, base level elevations corresponding to each paleolandsurface were obtained by projecting or extrapolating paleosurface remnant elevation(s) onto a vertical straight line above the current river trace (Figure 3b). Surface 1-bauxitic remnants were horizontally projected (Figure 3), sometime up to $50 \mathrm{~km}$ from the river. Inselberg tops with higher elevation than that of surface 2 relicts provide a minimum elevation for the bauxitic surface and were also projected horizontally. Surface 2 relicts commonly encompass altitudinal ranges on the slopes of bauxitic mesas (e.g., Figure $3 \mathrm{~b}$ ). The maximal and minimal elevations of surface 2 relict(s) were horizontally projected to reflect the amplitude of its local relief at each station (Figure 3b). Glacis form as concave upstream valley sides of 0.2 to $10^{\circ}$ in slope connected to the local base level (Grandin, 1976; Strudley et al., 2006; Strudley and Murray, 2007). Thanks to their duricrusted cover, remnants of glacis surfaces 3 and 4 have their original shape well preserved (e.g., Figure $3 b$ ). We therefore extrapolated the downslope shape of the glacis by picking points from their surface along a down-dip section towards the river (Figure 3b) and exponentially fitting those points using formula:

$$
z=z_{0}+H \exp ^{-(x / \sigma)}
$$

where $x$ is the horizontal distance to the river, $z$ is the elevation. $z_{0}$ is the minimum elevation of the considered geomorphic surface. $\sigma$ is a measure of the exponential reduction of elevation, i.e. a measure of inverse concavity, and $H$ is a constant set by the elevation amplitude of pediments surface. Base levels 3 and 4 elevation is calculated at the river. Elevation error is estimated using the derivative:

$$
\mathrm{d} z=\mathrm{d} z_{s r t m}+\mathrm{d} z_{0}+\exp ^{-\left(x / \sigma_{o p}\right)} \mathrm{d} A+H_{o p}\left(\frac{x}{\sigma_{o p}^{2}}\right) \exp ^{-\left(x / \sigma_{o p}\right)} \mathrm{d} \sigma
$$

where $\mathrm{dz}_{\text {srtm }}$ is the absolute error of SRTM DEM (5.6 m in Africa ; Farr et al., 2007). $\sigma$ index represents the inverse of concavity of the exponential fit and $H_{o p}$ and $\sigma_{o p}$ are the 
optimum values given by the interpolation. Distribution of $\sigma_{o p}$ is quasi-normal and centered on 300 (Figure 4), attesting to the repeatability of the glacis shape over the study area and justifying the use of the fit formula (equation 1). At most stations, the error induced by the extrapolation of glacis base levels is smaller than the data point size (Figure $3 \mathrm{~b}$ and 5). This, together with the little skewed distribution of $\sigma_{o p}$ (Figure 4) shows that the extrapolated paleobase levels are robust. At stations where glacis remnants are not large enough to be confidently extrapolated, the lowest elevation of the remnant the closest to the river is horizontally projected.

Given the long projection distance of some bauxite relicts and the fact that the bauxitic surface has a regional relief (Chardon et al., 2006), the envelope topography of the Eocene landscape was drawn passing through surface 1 elevation data points (Figure 5). The curve joining the elevation of the lowest remnants of surface 2 has been drawn to represent the maximal elevation of rivers paleo-long profile 2 (Figure 5). Long profiles 3 and 4 were drawn from extrapolated surfaces 3 and 4 remnants or their projected lowest remnants. Modern profiles 5 were automatically extracted from the SRTM digital elevation model (Figure 5). Incision rates III, IV and V (representing time intervals 24-11, 11-6 and 6-0 Ma, respectively) were plotted along river profiles (Figure 5). Incision rates IV and $V$ were obtained using base levels 3, 4 and 5 at each station by integrating the elevation error resulting from the extrapolation (Figure 5). Maximum values of incision rate III are derived from the difference between paleoprofiles 2 and 3 . Detection and qualification of steps on paleoprofiles depend on data resolution. Analysis of the current and past long profiles allows defining knickzones as $<90 \mathrm{~km}-$ long river segments of more than $1 \%$ slope between two longer adjoining linear segments of 0.1 to $2 \%$ slopes. Knickpoints, which are sharper by definition, are only rarely detectable on the reconstructed profiles. Although the river profiles have 
undergone long-wavelength distortion (section 5.2), their differential elevations constitute a meaningful estimate of incision. Likewise, comparing the relative geometry of short $(<100 \mathrm{~km})$ successive paleo-river segments is appropriate and relevant.

\section{Results}

We separate the studied river systems into four groups according to their location in the West African drainage (Figure 1). Group A includes the rivers draining the northwestern slope of the Guinean rise (Senegal and Gambia). Group B includes the short rivers draining the southern slope of the Guinean rise (Kakrima and Mano). Group C comprises the long southern rivers (Bandama, Comoé and Volta) and group D corresponds to the Niger drainage. The Niger River is divided in two segments (High and Low Niger) on both sides of the Niger inland delta (Figure 1). To facilitate the description of results, we show one representative example for each group (i.e. the Senegal, Kakrima, Volta and Niger main stream channels for groups A, B, C and D respectively) on Figure 5. The entire set of reconstructed profiles can be found in the data repositories.

\section{1. Overall profiles shape and early drainage reorganization}

Past and modern long profiles of group A have a nearly straight, very low gradient slope across the Senegalo-Mauritanian basin (Figure 5a). Upstream parts of the profiles are steeper, generally stepped, with an increased slope (up to $0.7 \%$ ) for rivers draining the Western Guinean rise. Group B comprises the shortest rivers with paleoand modern long profiles that have the steepest mean slopes (> $2 \%$ o) and are the most stepped (Figure 5b). The paleo and modern profiles of the Volta (group C) and Low Niger (group D) reveal a two-stage evolution. Indeed, the envelope of surface 1 
underlines a divide whose crest lies between 200 and $750 \mathrm{~km}$ inland (Figures 5c and 5d). Groups $\mathrm{C}$ and $\mathrm{D}$ rivers have incised this divide mostly during incision period II. This, together with the overall evolution of group A and B rivers indicates drainage reorganization during period II resulting from the dissection of an Eocene marginal upwarp that survived or was rejuvenated in the Guinean rise (Beauvais and Chardon, 2013). This rearrangement involved capture of pre-45 Ma internal drainages by at least the Volta and Low Niger. More generally, depressions in the envelope of surface 1 (e.g., Figure 5c) are indicative of transverse paleovalleys before drainage rearrangement and/or second-order captures during rearrangement (see also data repositories). The fact that the post-rearrangement, 24 Ma old surface 2 systematically dips towards the current main drains warrants calibration of post 24 Ma incision.

Group C profiles 2 to 5 show a nearly parallel evolution. They are made of straight, low slope $(<0.1-0.3 \%$ ) segments hundreds of kilometers long, which are separated by knickzones, notably those highlighted on Figure 1. Profiles 2 to 5 converge and merge towards the coast downstream of the lower regional knickzone (Figure 5b). The High Niger River shows strongly concave paleo and modern profiles (Figure 5e), whereas post-surface 1 Low Niger profiles have low and slightly convex slopes diverging downstream (Figure 5d). Paleo long profiles reveal that knickzones on modern profiles have persisted since at least profile 3 (Figure 5).

Analysis of geological maps shows that those recurrent knickzones coincide with lithological contrasts expressed in the topography (Figure 5). Two main contrasts are distinguished, those related to steep contacts between greenstone belts and their adjoining granite-gneiss terrains and those formed across tabular sandstones. In the first case, the knickzone horizontally encompasses the along-river width of a greenstone belt or the lower limit of the knickzone coincides with the contact between a wide 
257 greenstone belt and granitogneisses. In the second case, the most common configuration

258 is the lower limit of the knickzone coinciding with the basal unconformity of the

259 sandstones.

260

261

\section{2. Northwestern rivers (group A)}

262 On group A rivers, post-surface 2 incision generally increases from the 263 extremities towards the central part of the profiles resulting in an increasing concavity 264 of the profiles through time. This is particularly the case for incision IV, and, to a lesser 265 extent, incision III (Figure 5a). In the Guinean rise, profiles 3 and 4 show mainly 266 convex segments, with local high incision rates (up to $20 \mathrm{~m} / \mathrm{my}$ ) for period IV (Figure

267 5a). Overall, incision is rather uniform during period III and becomes more localized 268 afterwards though accompanied by a decrease of the incision rates. Incision V is locally 269 enhanced (up to $10 \mathrm{~m} / \mathrm{my}$ ) by the formation of new knickzones on profile 5 (Figure $5 \mathrm{a}$ ).

271 4. 3. Short southern rivers (group B)

272 Long (> $100 \mathrm{~km}$ ) segments of paleoprofiles 2, 3 and 4 are convex (Figure 5b).

273 The stepped character of the profiles is accentuated through time by the apparition of 274 shorter convex segments, particularly during incisions IV and V. Post surface 2

275 incisions tend to increase from the extremities towards the central part of the profiles, 276 with locally enhanced incision during incisions IV and V that led to the formation of the 277 modern knickzones (Figure 5b). This attests to a heterogeneous incision pattern during 278 these periods ( 2 to $25 \mathrm{~m} / \mathrm{my}$ ), as opposed to rather distributed incision during period III 279 (about $10 \mathrm{~m} / \mathrm{my}$ in average). Incision gradients are located in between knickzones, the 280 highest peaks being located mainly upstream. Elevation difference between surface 1 
and the modern profiles implies a maximum incision of the slope of the Guinean rise of the order of $400 \mathrm{~m}$ (but equivalent to only $9 \mathrm{~m} / \mathrm{my}$ over the last $45 \mathrm{Ma}$ ) (Figure $5 \mathrm{~b}$ ).

\section{4. Long southern rivers (group C)}

The overall geometry of river long profiles has been acquired since the establishment of profiles 2 . The two regional knickzones systematically coincide with lithological contrasts and occurred at least since profile 3 (Figure 5c). A mean cumulated incision of less than $50 \mathrm{~m}$ is derived from parallel and close profiles 3 to 5 . Rivers show a rather parallel evolutionary pattern of profiles 2 and 3 along the central river segment comprised between the two regional knickzones (Figure 5c). This is indicative of a rather distributed incision III of ca. $7 \mathrm{~m} / \mathrm{my}$. By contrast, lower gradient of profile 2 diverges from profile 3 downstream of the upper regional knickzone and the two profiles tend to merge towards the coast (Figure 5c). Overall, eastern rivers of group C such as the Volta become increasingly stepped with time (Figure 5c).

\section{5. Niger River (group D)}

Although the recurrence of the two regional knickzones is not readily documented along the Low Niger, the overall pattern of profiles 2 to 5 is roughly comparable to that of the Volta, with a diversion of the profiles downstream of the inland delta (e.g., comparison of Figures $5 \mathrm{c}$ and 5d). This attests to an increase in Neogene incision(s) downstream the inland delta. The overall long wavelength convexity of profiles 3 and 4 is documented between 200 and $1200 \mathrm{~km}$ (Figure 5d). Nearly parallel profiles 2 to 4 converge within the Iullemmeden basin. A single knickzone may be documented on profile $3(\mathrm{ca} .450 \mathrm{~km})$ and none may be detected on profile 4 (Figure 5d). But this may be due to the low resolution of our dataset 
downstream of the Iullemmeden basin. A two-step knickzone occurs on the modern profile between 800 and $1000 \mathrm{~km}$ (Figure 5d). Incision period V created high local relief compared to that of period IV, particularly downstream of the lower regional knickzone (e.g., Figure 5d). Incision V becomes limited approaching the inland delta and the coast $(<5 \mathrm{~m} / \mathrm{my})$ and increases towards the central part of the profiles, with the highest incision rates downstream of the two-step knickzone of profile 5 (ca. $10 \mathrm{~m} / \mathrm{my}$ during periods II, IV and V; Figure 5d).

Paleo long river profiles of the High Niger (Figure 5e) are comparable to those of the Senegal (group A, e.g., Figure 5a). All the profiles converge downstream and merge entering the inland delta, which is preceded by a knickzone $400 \mathrm{~km}$ upstream (Figure 5e). Profiles 2 to 5 may be divided in two segments i.e., a lower, ca. $1000 \mathrm{~km}$ long and low gradient segment of parallel profiles and an upper, very steep and short segment within the Guinean rise (Figure 5e). Most of the incision along the High Niger took place during period II (locally more than $15 \mathrm{~m} / \mathrm{my}$ ). Incision rates III to $\mathrm{V}$ are remarkably low and uniform along the lower segment $(<6 \mathrm{~m} / \mathrm{my})$ and may locally attain $15 \mathrm{~m} / \mathrm{my}$ in the Guinean rise (Figure $5 \mathrm{e}$ ). The overall tendency of the upper Niger is an increase in the concavity of river profiles.

\section{Interpretation and discussion}

\subsection{Incision dynamics and river profiles evolution}

The present analysis shows that the overall shape of river profiles was acquired at least since $\sim 11 \mathrm{Ma}$, and most probably $\sim 24 \mathrm{Ma}$ (Figure 6 ). The overall concavity of the successive river long profiles increased over the Neogene as a result of the pinning down of their two extremities (Figure 6). This attests to the horizontal stability of the divides and efficient adaptation to relative sea level change at the coast over the 
331 Neogene. This very long-term divide stability, which has also been documented for the

332 Southeastern margin of Australia (e.g., Young, 1989) contrasts with the view of

333 drainage networks as "permanently" reorganizing in comparable passive margin

334 contexts (Willett et al., 2014). We suggest that following drainage rearrangement

335 (section 4.1), local relief and regional topography of West Africa acquired by the end of

336 erosion period II had attained a threshold preventing divide migration after the

337 Oligocene. Neogene divide stability over West Africa implies long-term stable

338 geometry of drainage basins, which has major implications for understanding source-to-

339 sink systems (Grimaud et al., 2014). This stability is reflected by low incision rates

340 through space and time with more than $75 \%$ of the data below $10 \mathrm{~m} / \mathrm{my}$ and medians

341 and means between 3 and $15 \mathrm{~m} / \mathrm{my}$ (Figure 7). The last incision period would have

342 recorded the smallest incision rates. Highest incision rates correspond to the steepest

343 rivers draining the Guinean rise (groups A and B; Figure 7; upper Niger; Figure 5e),

344 suggesting a control of potentially old, large-scale reliefs on incision heterogeneities

345 (Beauvais and Chardon, 2013). To summarize, the present work provides constraints on

346 boundary conditions and incision rates for large-scale surface process models in

347 "stable" continental environments over geological time scales.

348 Our results reveal the long lasting maintenance of lithogenic knickzones along

349 most rivers for at least $\sim 11$ my and most probably 24 my (Figure 6). Similar recurrent

350 knickzones were documented in the comparable morphotectonic context of Eastern

351 Australia (Bishop et al., 1985; van der Beek and Bishop, 2003). The concavity and

352 stepped character of West African river long profiles have been amplified since the

353 Early Neogene by very slow, non-uniform and unsteady incision in between stationary

354 knickzones (Figures 5 and 6). Type-evolutionary patterns of rivers segments comprised

355 between stationary knickzones are shown on Figure 8. Parallel evolution by strict 
uniform incision (Figure 8a) is characteristic of the High Niger River since $24 \mathrm{Ma}$

357 (Figures 5e and 6d). Such an evolution is also locally observed on segments of the Low

358 Senegal, Volta and Low Niger (Figure 5a, 5c and 5d). In all cases, strict uniform incision is systematically of very low rate $(<5 \mathrm{~m} / \mathrm{my})$. Strict downstream rejuvenation (Figure $8 \mathrm{~b}$ ) is not recorded by any of the studied rivers (Figure 5). Instead, knickzones may be created by differential incision (Figure 8c), as exemplified by the Senegal and Low Niger (at 1600-1800 km in Figure 5a and 400-500 km and 800-1000 km in Figure 5d). However, most knickzones in West Africa have been amplified or smoothed instead of having been created since $24 \mathrm{Ma}$ (Figure 5). This resulted in slope lowering of most river segments, reflecting finite incision gradients along those segments (Figure 8d). This situation is best exemplified along the Senegal (at 1000-1200 km), Kakrima (at 100-300 km), Volta (600-800 km) and Low Niger (at 400-800 km and 1700-2000 km) (Figure 5). exception of their lowermost reaches i.e., group $\mathrm{C}$ and $\mathrm{D}$ rivers during period IV (Figures 5 and 6, see below). In other words, repercussion of a major relative sea level 
381 This warrants caution in using knickzones' height as a gauge of discrete uplift and

382 figuring river profile response to uplift by headward propagation of such knickzones

383 using stream-power river incision models. Accordingly, uplift histories retrieved from

384 river profiles inversion procedures based on such models could be challenged,

385 particularly those obtained for reliefs of the deep interior of the African continent (see

386 Roberts and White, 2010 and Paul et al., 2014). As opposed to uplift, our results would

387 argue for a dominant control of climate-driven erosion processes on incision dynamics

388 of big non-orogenic drainages over geological time scales (Beauvais and Chardon,

389 2013).

390

\subsection{Anomalies in river profiles and lithospheric deformation}

Long wavelength (300 - $500 \mathrm{~km}$ long) upward convex segments of modern river profiles define a large domain comprising the Upper Volta and upper part of the Low

Niger drainages (Figures 6c, 6d and 9). Our field observations and digital topographic data further indicate that this area coincides with portions of the Niger drainage that have incised their lowermost terrace. The convex river segments do not exceed $50 \mathrm{~m}$ in amplitude and are interpreted to reflect active transient adjustment by enhanced incision. The dynamics of two other major segments of the Niger and Volta drainage have been modified in the recent geological past. Indeed, the lower portion of the High

400 Niger and the Gondo flew to NE before becoming alluvial plains (i.e., internal deltas) 401 around the end of the Pliocene (Figure 9). These changes in river dynamics may result 402 from slope decrease of those NE flowing drains. Both the upward convex river segments and internal deltas are interpreted to respond to southwestward growth of the

404 Hoggar swell, which would be comparable to the lateral propagation of an active 405 anticline (Keller et al., 1999), the direction and sense of propagation being determined 
by the northeastward displacement of the African plate with respect to the Hoggar plume and/or to asthenospheric flow under the plate (Figure 9). Swell growth would induce slope decrease on the drains flowing towards the propagating swell to create internal deltas, whereas drains flowing across the propagating swell undergo enhanced incision to keep pace with growing uplift. The area of active uplift (Figure 9) mimics the domain of positive dynamic topography expected from mantle circulation models of Forte et al. (2010), reinforcing the causal link suggested here between mantle dynamics and river profiles evolution.

Long wavelength (500 - $1000 \mathrm{~km})$ convexities of the lower part of river profiles 2 to 4 are documented for drainages C and D (Figures 6c and 6d). For group C, convexity seems to increase with time (from profile 3 to profile 2) and has maximum amplitude of ca. $100 \mathrm{~m}$ and a wavelength of ca. $500 \mathrm{~km}$. This convexity is replaced on the current profile by the lower regional knick zone and a concave lowermost portion of the rivers (Figure 6c). Warping is also documented on the lower Niger particularly on nearly parallel profiles 2 and 3, with a ca. $200 \mathrm{~m}$ amplitude and $1000 \mathrm{~km}$ wavelength convexity (Figure 6d). The convexity amplitude of profile 4 is much lower, indicating that profiles 2 and 3 underwent warping mainly before $6 \mathrm{Ma}$. The last erosion period (i.e., post $6 \mathrm{Ma}$ ) is also characterized by the creation of the major (double) regional knickzone and the acquisition of a concave lowermost profile (Figure 6d). Warping and post-6 Ma rejuvenation by knickzone creation of the lowermost portion of group $\mathrm{C}$ and D rivers are interpreted to result from flexural uplift of the continental margin (e.g., Gilchrist and Summerfield, 1990). Flexure was enhanced by (i) the narrowness of the two transform segments of the margin in this area (Figure 9), (ii) high and increasing Neogene clastic sedimentation rates at its foot (Séranne, 1999; Jermannaud et al., 2010) and (iii) onshore denudation (Beauvais and Chardon, 2013). The 500-1000 km 
431 wavelength of the flexure is too large to reflect only warping across a steep margin and

432 is typical of asthenospheric-scale processes (e.g., McKenzie and Fairhead, 1997). We

433 suggest that flexural uplift of the margin combined with the growth of the Hoggar swell

434 (this work) and/or with the uplift of the continent (e.g., Burke, 1996) to produce such a

435 wavelength.

\section{5.3. Open questions}

438 Creation or amplification of major knickzones achieves post 6 Ma rejuvenation 439 of the warped lower portion of rivers flowing to the transform portions of the West

440 African margin (Figure 6). The contribution, if any, of the Quaternary eustatic cycles to

441 the creation of those knickzones may not be evaluated and whether these knickzones are

442 actively migrating and/or evolve by knickpoint retreat should be the focus of future

443 research. Knickpoint retreat is inferred to have been instrumental in the Plio-Pleistocene

444 rejuvenation of the Appalachian landscape in a passive margin context comparable to

445 that of West Africa (Gallen et al., 2013). Upstream West African drainage did not

446 evolve by large wave(s) of headward migrating knickzones but our results are based on

447 very long term measurements that may have averaged discrete periods of fast incision

448 (Gardner et al., 1987). Hence, they do not allow testing whether knickpoint retreat

449 process actually contributed to shaping individual river segments bounded by recurrent

$450 \quad$ knickzones.

451 Likewise, documented distortion of portions of past river profiles poses the issue 452 of whether rivers maintained their concavity against upwarping of abandoned base level 453 markers or increased their overall concavity from more convex states. In the case of the 454 lower reaches of group $\mathrm{C}$ and D rivers having undergone marginal flexural uplift, the 455 first situation would clearly apply. The second situation could apply to the rest of the 
456 drainage with the noticeable exception of the northern slope of the Guinean rise (group

457 A rivers; Figures 5a and 6a). But in absence of independent geological constraints on

458 the potential relative uplift of the rise during the Cenozoic, it is not possible to evaluate

459 its impact on the acquisition of long river profiles of West Africa.

460

\section{6. Conclusions}

462 The spatial analysis of dated and regionally correlated incision markers allows

463 calibrating incision dynamics of big West African rivers over the last 45 my and

464 quantifying the evolution of their long profiles since $24 \mathrm{Ma}$. Incision rates are

465 distributed spatially and remained below $10 \mathrm{~m} / \mathrm{my}$ and mostly below $5 \mathrm{~m} / \mathrm{my}$. Spatial

466 stability of both the outlets and divides of the rivers since 24 Ma imposed increasing

467 overall concavity of their long profiles, which was achieved by contrasted adjustment of

468 river segments separated by persistent lithogenic knickzones. River segments evolve by

469 preferential slope decrease or uniform incision in between nodes defined by the pinned

470 knickzones of evolving amplitude. Therefore big non-orogenic rivers do not respond

471 simply to relative sea level change, which is unlikely to be recorded far inland in the

472 form of purely retreating knickzones. Accordingly, knickzone height or position on such

473 rivers are not obvious gauges of base level fall and caution is required in retrieving

474 regional uplift histories of deep continental interiors from river long profiles inversion

475 procedures. Rather uniform and slow incision of large non-orogenic drainage basins

476 allows distortion and anomalies in river profiles to record subtle long wavelength

477 surface uplift due to hot spot swell growth and flexure of continental margins,

478 emphasizing their potential as gauges of dynamic topography.

479

480 Acknowledgments 

the CNRS and WAXI. We thank S. Carretier, S. Bonnet, P. van der Beek and G. Hérail

483 for fruitful discussions and Ph. Dussouillez for support. We are indebted to F. Pazzaglia

484 for very constructive reviews. The manuscript benefited from comments by K. Burke

485 and anonymous reviewers. We acknowledge AMIRA International and the industry

486 sponsors, including AusAid and the ARC Linkage Project LP110100667, for their

487 support of the WAXI project (P934A) as well as the Geological Surveys/Departments

488 of Mines in West Africa as sponsors in kind of WAXI.

489 


\section{References}

Beauvais, A., Chardon, D., 2013. Modes, tempo and spatial variability of Cenozoic cratonic denudation: The West African example. Geochem. Geophys. Geosyst. 14, 1590-1608, doi:10.1002/ggge.20093.

Beauvais, A., Ruffet, G., Hénocque, O., Colin, F., 2008. Chemical and physical erosion rhythms of the West African Cenozoic morphogenesis: The ${ }^{39} \mathrm{Ar}-{ }^{40} \mathrm{Ar}$ dating of supergene K-Mn oxides. J. Geophys. Res. 113, F04007, doi:10.1029/2008JF000996.

Bishop, P., Young, R.W., McDougall, I., 1985. Stream profile change and longterm landscape evolution. Early Miocene and modern rivers of the East Australian highland crest, central New South Wales, Australia. J. Geol. 93, 455-474.

Bishop, P., 1985. Southeast Australian late Mesozoic and Cenozoic denudation rates: A test for late Tertiary increases in continental denudation. Geology 13(7), 479482.

Boulangé, B., Delvigne, J., Eschenbrenner, V., 1973. Descriptions morphoscopiques, géochimiques et minéralogiques des faciès cuirassés des principaux niveaux géomorphologiques de Côte d'Ivoire. Cah. ORSTOM, sér. Géol. V(1), 59-81.

Boulangé, B., Millot, G., 1988. La distribution des bauxites sur le craton ouest-africain. Sci. Géol. Bull. 41(1), 113-123.

Burke, K., 1996. The African Plate. S. Afr. J. Geol. 99, 339-409.

Burke, K., Gunnell, Y., 2008. The African Erosion Surface: A Continental-Scale Synthesis of Geomorphology, Tectonics, and Environmental Change over the Past 180 Million Years. Geol. Soc. Am. Mem. 201, 1-66. 
513 Burke, K., Durotoye, B., 1971. Geomorphology and superficial deposits related to large 514 Quaternary climatic variations in South Western Nigeria. Z. Geomorph. 15, $515 \quad 430-444$.

516 Chardon, D., Chevillotte, V., Beauvais, A., Grandin, G., Boulangé, B., 2006. Planation, 517 bauxites and epeirogeny: One or two paleosurfaces on the West African margin? $518 \quad$ Geomorphology 82, 273-282.

519 Colin, F., Beauvais, A., Ruffet, G., Hénocque, O., 2005. First ${ }^{40} \mathrm{Ar} /{ }^{39} \mathrm{Ar}$ geochronology 520 of lateritic manganiferous pisolites: Implications for the Palaeogene history of a West African landscape. Earth Planet. Sci. Lett. 238(1-2), 172-188. doi:

Crosby, B.T., Whipple, K.X., 2006. Knickpoint initiation and distribution within fluvial networks: 236 waterfalls in the Waipaoa River, North Island, New Zealand. Geomorphology 82, 16-38.

Eschenbrenner, R., Grandin, G., 1970. La séquence de cuirasses et ses différenciations entre Agnibiléfrou et Diébougou (Haute-Volta). Cah. ORSTOM, Sér. Géol. 2(2), 205-246.

Farr, T.G., Rosen, P.A., Caro, E., Crippen, R., Duren, R., Hensley, S., Kobrick, M., Paller, M., Rodriguez, E., Roth, L., Seal, D., Shaffer, S., Shimada, J., Umland, J., Werner, M., Oskin, M., Burbank, D., Alsdorf, D., 2007. The Shuttle Radar Topography Mission. Rev. Geophys. 45, RG2004.

Forte, A.M., Quéré, S., Moucha, R., Simmons, N.A., Grand, S.P., Mitrovica, J.X., Rowley, D.B., 2010. Joint seismic-geodynamic-mineral physical modelling of African geodynamics: A reconciliation of deep-mantle convection with surface geophysical constraints. Earth Planet. Sci. Lett. 295, 329-341. 
Gallen, S.F., Wegmann, K.W., Bohenstielhl, D.R., 2013. Miocene rejuvenation of topographic relief in the Southern Appalachians. GSA Today 23(2), 4-10, doi:10.1130/GSATG163A.1.

Gardner, T.W., Jorgensen, D.W., Shuman, C., and Lemieux, C.R., 1987. Geomorphic and tectonic process rates: Effects of measured time interval, Geology 15(3), 259-261, doi:10.1130/0091-7613(1987)15<259:GATPRE>2.0.CO;2.

Gilchrist, A.R., Summerfield, M.A., 1990. Differential denudation and flexural isostasy in formation of rifted-margin upwarps. Nature 346, 739-742.

Grandin, G., 1976. Aplanissements cuirassés et enrichissement des gisements de manganèse dans quelques régions d'Afrique de l'Ouest. Mém. ORSTOM 82, Paris, France.

Grimaud, J.-L., Chardon, D., Rouby, D., Beauvais, A., 2014. Quantifying denudation of the West African passive-transform margin: implications for Cenozoic erosion budget of cratons and source-to-sink systems. Geophys. Res. Abstr. 16, EGU2014-9913.

Hénocque, O., Ruffet, G., Colin, F., Féraud G., 1998. ${ }^{40} \mathrm{Ar} /{ }^{39} \mathrm{Ar}$ dating of West African lateritic cryptomelanes. Geochim. Cosmochim. Acta 62(16), 2739-2756.

Jeffery, M.L., Ehlers, T.A., Yanites, B.J., Poulsen, C.J., 2013. Quantifying the role of paleoclimate and Andean Plateau uplift on river incision. J. Geophys. Res. Earth Surf. 118, 852-871. doi: 10.1002/jgrf.20055.

Jermannaud P., Rouby, D., Robin, C. Nalpas, T., Guillocheau, 2010. Plio-Pleistocene Sequence Stratigraphic architecture of the eastern Niger delta: a record of eustasy and aridification of Africa. Mar. Pet. Geol. 27, 810-821 
Keller, E.A., Gurrola, L., Tierney, T.E., 1999. Geomorphic criteria to determine the direction of lateral propagation of reverse faulting and folding. Geology 27, 515-518.

King, L.C., 1948. On the age of African land-surfaces. Q. J. Geol. Soc. London 104, 439-459.

McKenzie, D., Fairhead, D., 1997. Estimates of the effective elastic thickness of the continental lithosphere from Bouguer and free air gravity anomalies. J. Geophys. Res. 102, 27523-27552.

Michel, P., 1973. Les bassins des fleuves Sénégal et Gambie : étude géomorphologique. Mém. ORSTOM 63, Paris, France.

Paul, J.D., Roberts, G.G., White, N., 2014. The African landscape through space and time. Tectonics 33(6), 898-935, doi:10.1002/2013TC003479.

Pazzaglia, F.J., Gardner, T.W., Merritts, D.J., 1998. Bedrock fluvial incision and longitudinal profile development over geologic time scales determined by fluvial terraces, in: J. Tinkler, Wohl, E. (Eds.), Rivers Over Rock: Fluvial Processes in Bedrock Channels, Geophys. Monogr. Ser., vol. 107. AGU, Washington, DC, pp. 207-235.

Roberts, G.G., White, N., 2010. Estimating uplift rate histories from river profiles using African examples. J. Geophys. Res. Solid Earth 115, B02406.

Schumm, S.A., 1993. River response to baselevel change: Implications for sequence stratigraphy. J. Geol. 101, 279-294.

Séranne, M., 1999. Early Oligocene stratigraphic turnover on the West Africa continental margin: a signature of the Tertiary greenhouse-to-icehouse transition? Terra Nova 11(4), 135-140. 
587

601

Strudley, M.W., Murray, A.B., 2007. Sensitivity analysis of pediment development through numerical simulation and selected geospatial query. Geomorphology $88,329-351$.

Strudley, M.W., Murray, A.B., Haff, P.K., 2006. Emergence of pediments, tors, and piedmont junctions from a bedrock weathering-regolith thickness feedback. Geology 34, 805-808.

Summerfield, M.A., 1991. Global geomorphology; an introduction to the study of landforms. Longman Scientific \& Technical, Harlow, UK.

Summerfield, M.A., 1996. Tectonics, geology and long-term landscape development, in: W.M. Adams, A.S. Goudie, R. Orme, A. (Eds.), The Physical Geography of Africa. Oxford University Press, Oxford, UK, pp. 1-17.

van der Beek, P., Bishop, P., 2003. Cenozoic river profile development in the Upper Lachlan catchment (SE Australia) as a test of quantitative fluvial incision models. J. Geophys. Res. 108(B6), 2309.

Vasconcelos, P. M., Brimhall, G. H., Becker, T. A., Renne, P. R., 1994. ${ }^{40} \mathrm{Ar} /{ }^{39} \mathrm{Ar}$ analysis of supergene jarosite and alunite: Implications to the paleoweathering history of the western USA and West Africa. Geochim. Cosmochim. Acta 58(1), 401-420.

Vogt, J., 1959. Aspects de l'évolution morphologique récente de l'ouest africain. Ann. Géog. Fr. 68, 367, 193-206.

Whipple, K.X., Tucker, G.E., 1999. Dynamics of the stream-power river incision model; implications for height limits of mountain ranges, landscape response timescales, and research needs. J. Geophys. Res. 104 (B8), 17661-17674, doi: 10.1029/1999JB900120. 
608 Willett, S.D., McCoy, S.W., Perron, T.J., Goren, L., Chen C-Y., 2014. Dynamic

609 reorganization of river basins. Science 343, 1248765,

610 doi:10.1126/science. 1248765.

611 Young, R.W., 1989. Crustal constraints on the evolution of the continental divide of

612 eastern Australia. Geology 17, 528-530.

613 


\section{$614 \quad$ Figure captions}

615

616 Figure 1. (a) Topography, drainage and selected geologic and geomorphic features of

617 West Africa. Topography is derived from smoothing of the Shuttle Radar Topography

618 Mission DEM to $5 \mathrm{~km}$ resolution. Thick grey lines labeled 1 and 2 refer to the lower

619 and upper regional knickzones, respectively. Capital letters refer to the studied groups

620 of rivers. A - northwestern rivers (long profiles shown in Figure 5a); B - short southern

621 rivers (Figure 5b); C - long southern rivers (Figure 5c); D - Niger River (Figure 5d). (b)

622 Modern long profiles of selected rivers. The lower and upper regional knickzones'

623 elevation ranges are indicated by dark and light grey bands numbered 1 and 2,

624 respectively.

625

626 Figure 2. Lateritic paleolandsurface sequence and incision chronology of West Africa

627 (synthesized after Michel, 1973; Beauvais et al., 2008; Beauvais and Chardon, 2013).

628

629 Figure 3. Example of a typical field station used to estimate local paleo-base levels

630 (Station 11 along the Bafing, corresponding to the upper Senegal River; Figures 1a and

631 5a). (a) Google Earth view (left) with its geomorphic interpretation (right). (b) Cross-

632 section drawn on Figure 3a showing the distribution of lateritic paleolandsurface relicts

633 and the method by which they are projected or extrapolated above today's river courses.

634

635 Figure 4. Distribution of the optimum inverse concavity $\sigma_{o p}$ in the exponential fits of 636 pediment surfaces 3 and 4 .

637 
638 Figure 5. Reconstructed paleo- and modern river long profiles and corresponding

639 incision rates. For each river group, the case of the most representative river is shown.

640 (a) Northwestern rivers (group A). (b) Short southern rivers (group B). (c) Long

641 southern rivers (group C). (d) Low Niger River (group D). (e) High Niger River (group

642 D). Paleoprofiles 2 are overestimated in elevation. Rivers and river groups are located

643 on Figure 1a. The complete set of river long profiles may be found in the data

644 repository.

645

646 Figure 6. Synthetic representation of the successive West African paleo-long river

647 profiles. (a) Northwestern rivers (group A). (b) Short southern rivers (group B). (c)

648 Long southern rivers (group C). (d) Niger River (group D) (location of river groups on

649 Figure 1a). Spiked segments of modern profiles correspond to $>300 \mathrm{~km}$ long upward-

650 convex segments (mapped in Figure 9). Elevation ranges of the lower and upper

651 regional knickzones are shown in grey and numbered 1 and 2, respectively.

652

653 Figure 7. Statistical summary (box and whiskers plots) of incision rates over West

654 Africa during periods III, IV and V (24-11, 11-6 and 6-0 Ma, respectively) for each

655 river group. Incision rates III are maximum values (see text for explanation). Incision

656 rates IV and V are calculated using the mean elevation of base levels 3, 4 and 5 where

657 available. Note that incision rates for period V may be slightly underestimated,

658 particularly on the lower course of rivers $\mathrm{C}$ and $\mathrm{D}$, where a small number of stations are

659 available on profile 4 but where locally large incision V occurs around modern

660 knickzones.

661 
662 Figure 8. Type evolutions of long river profile segments comprised between two

663 stationary knickzones (grey vertical stripes) and corresponding finite incision patterns

664 (vertical arrows). 1 - early river profile (green); 2 - late river profile (orange). (a)

665 Parallel evolution by uniform incision. (b) Knickpoint creation by downstream

666 rejuvenation. (c) Knickpoint creation by differential incision. (d) Slope decrease from

667 incision gradient.

668

669 Figure 9. Distribution of the main anomalies in the modern river long profiles of West

670 Africa and its interpretation in terms of long-wavelength lithospheric deformation of

671 mantle origin. Red arrows represent directions of horizontal propagation of the uplift

672 wave. Northeastward extensions of the Romanche (R) and St-Paul (SP) fracture zones

673 constitute the two main transform segments of the continental margin. 


\section{Highlights:}

- Reconstructed long profiles calibrate very slow incision (5 m/my) since Oligocene

- Profiles pinned-down at divide, outlet and stationary lithogenic knickzones

- Flexural uplift / dynamic topography mapped from profiles convexities \& anomalies

\section{Keywords:}

River long profiles; incision dynamics; knickzones; non-orogenic; Cenozoic; Africa 
Graphical Abstract (for review)

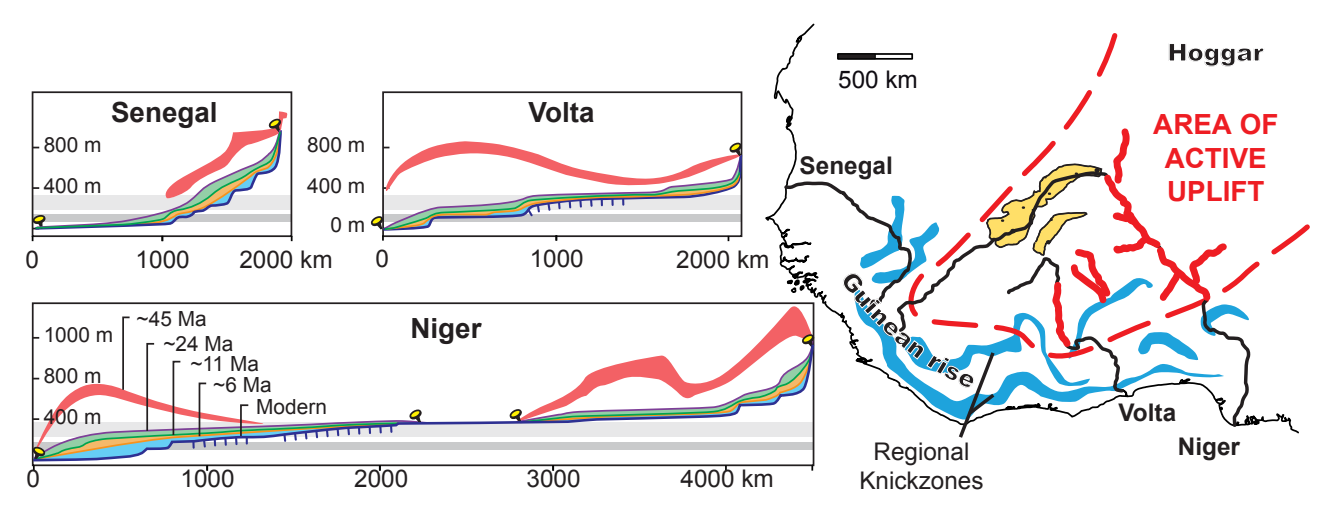




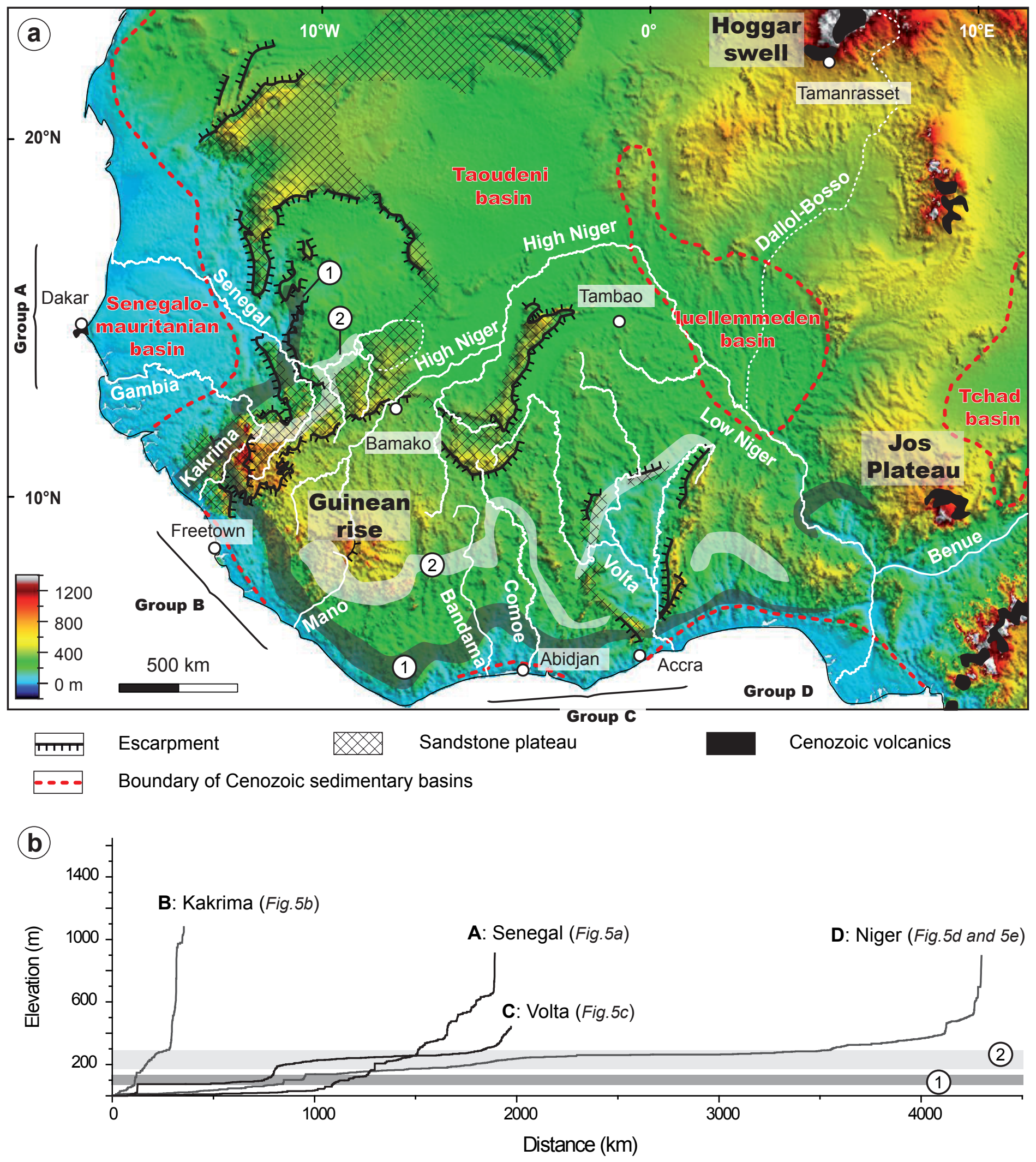

Grimaud et al., Figure 1 


\section{igure 2}

Click here to download Figure: Fig2.pdf

Paleolandsurface sequence and cover material

Paleolandsurface identification

(1) Bauxite

(«African»)

(2) Intermediate

(3) High glacis

(4) Middle glacis

In-situ

Type of

regolith

Type of duricrust weathering profiles Weathered colluvium and substrate

Ferricrete
Al-Fe crust Ferricrete
Abandonment Incision age (Ma) period

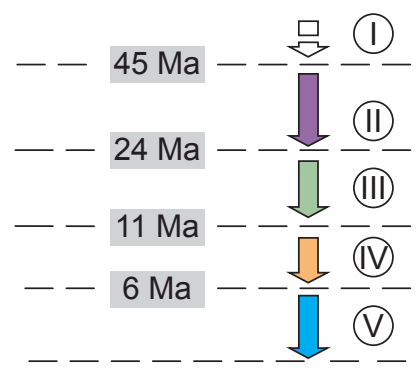

\section{Grimaud et al., Figure 2}


Click here to download Figure: Fig3.pdf
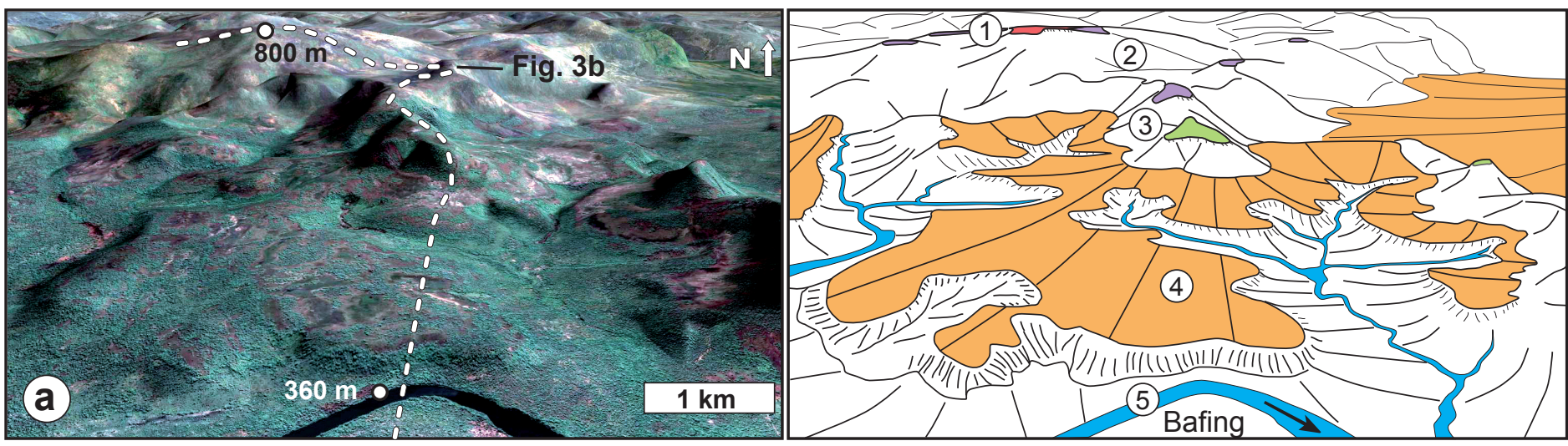

Vertical exageration $\times 3$

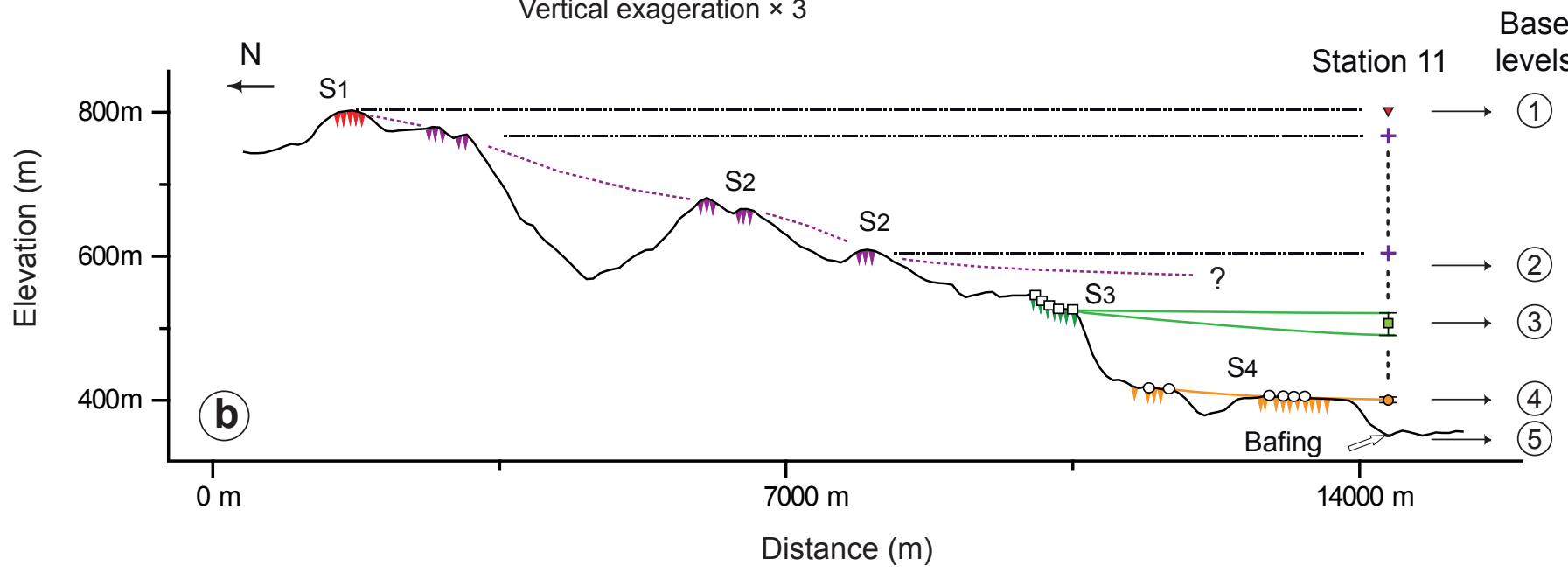

Grimaud et al., Figure 3 
Figure 4

Click here to download Figure: Fig4.pdf

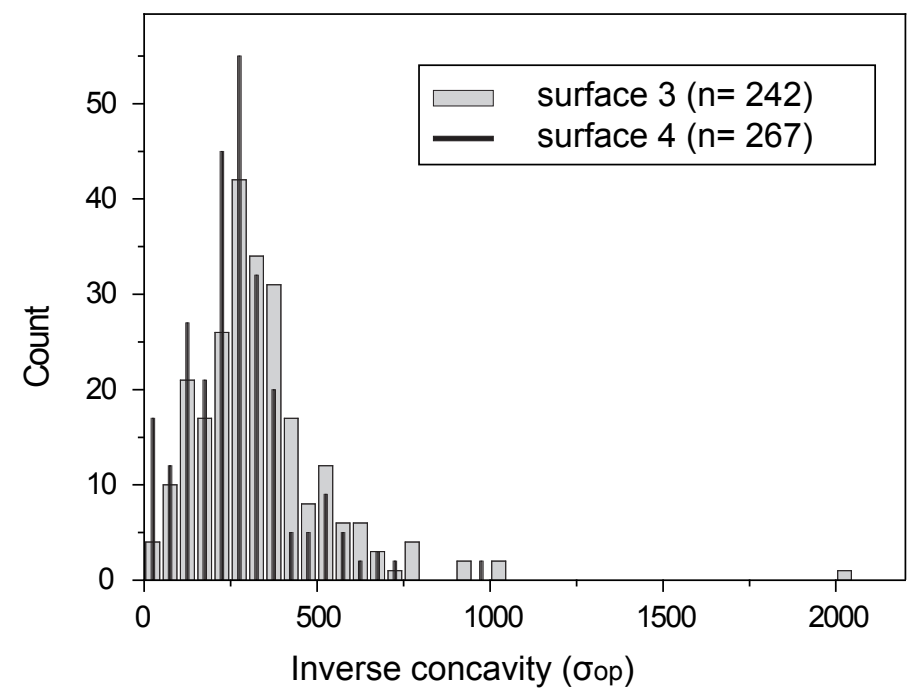

Grimaud et al., Figure 4 

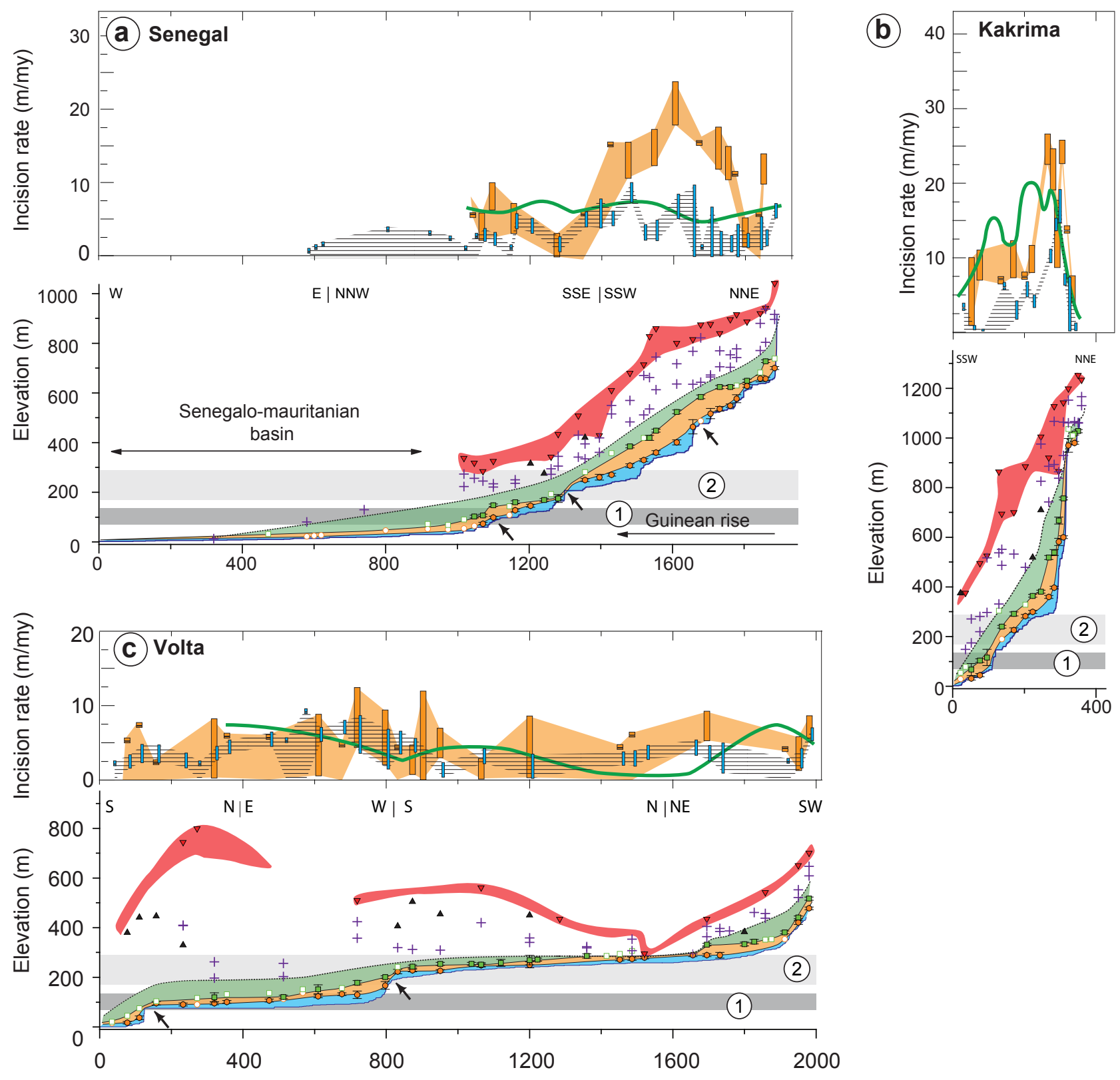

\section{Incision heights}

Geomorphic markers of paleo base levels

\begin{tabular}{|c|c|}
\hline$\nabla$ & S1 relict \\
\hline+ & S2 relict \\
\hline$\triangle$ & Inselberg \\
\hline$\square \circ$ & S3 / S4 lowest relicts \\
\hline 포 호 & $\begin{array}{l}\mathrm{S}_{3} / \mathrm{S}_{4} \text { extrapolated } \\
\text { base level }\end{array}$ \\
\hline
\end{tabular}

Modern morphology

$\square$ Modern river profile

(1) Lower regional knickzone

(2) Upper regional knickzone

Recurrent knickzone

\section{Incision III}

11 - $6 \mathrm{Ma} \square$ Incision IV

6 - $0 \mathrm{Ma} \square$ Incision V

Incision rates

$24-11 \mathrm{Ma} \square$ Incision III

11 - $6 \mathrm{Ma} \square$ Incision IV

6 - $0 \mathrm{Ma}$ 韭 Incision V 

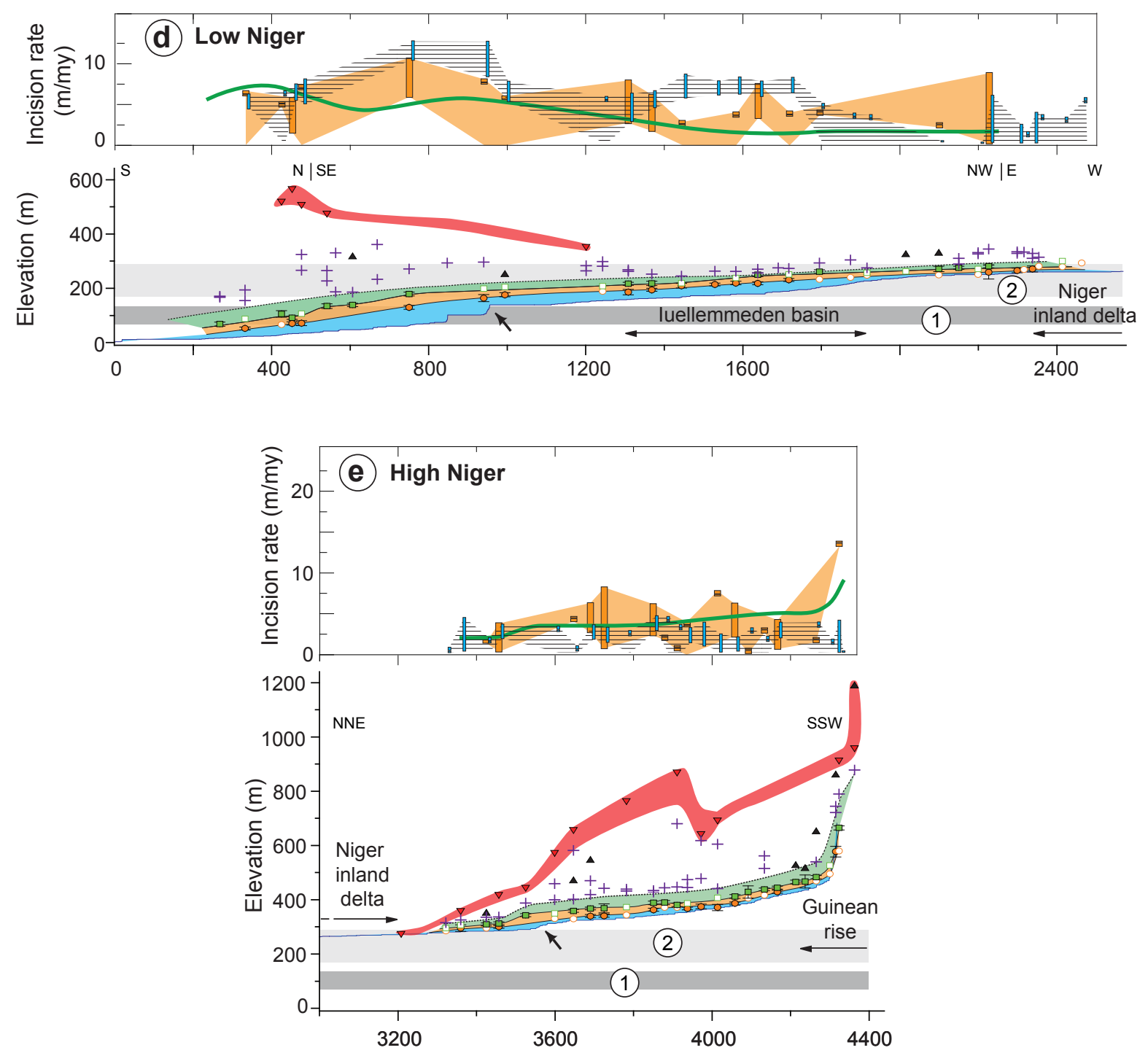

Grimaud et al., Figure 5 continued 
Click here to download Figure: Fig6.pdf

Northwestern rivers

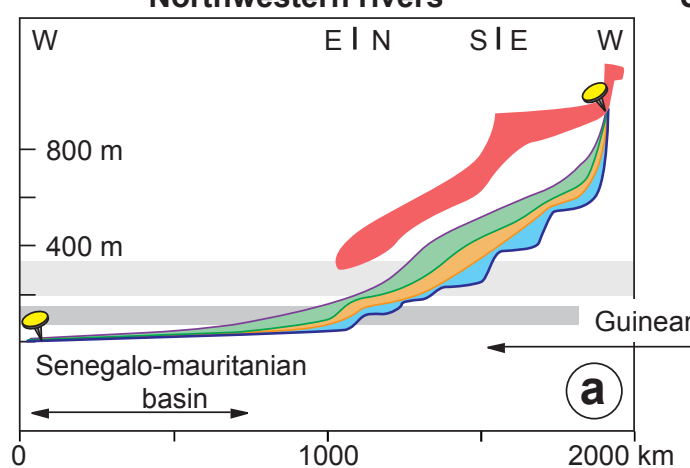

SSE (1) $\sim 45 \mathrm{Ma}$

(2) $\sim 24 \mathrm{Ma}$
Short southern rivers
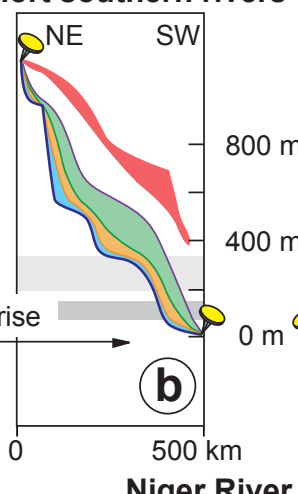

Long southern rivers

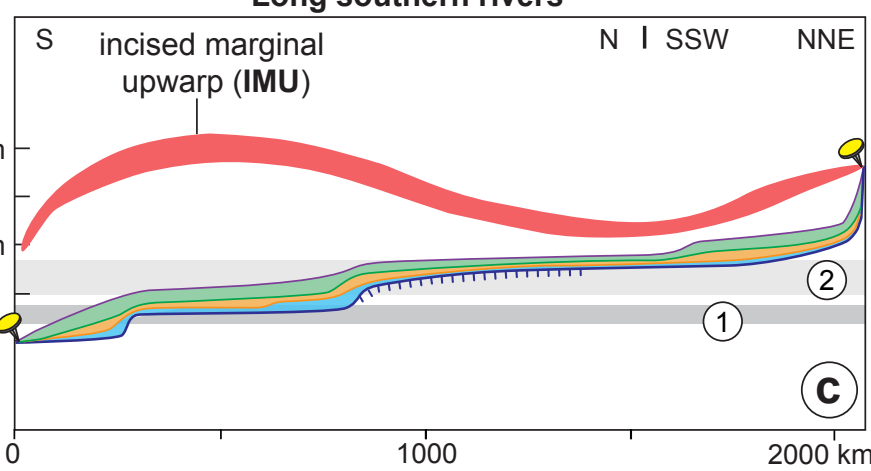

NNW I NE

W

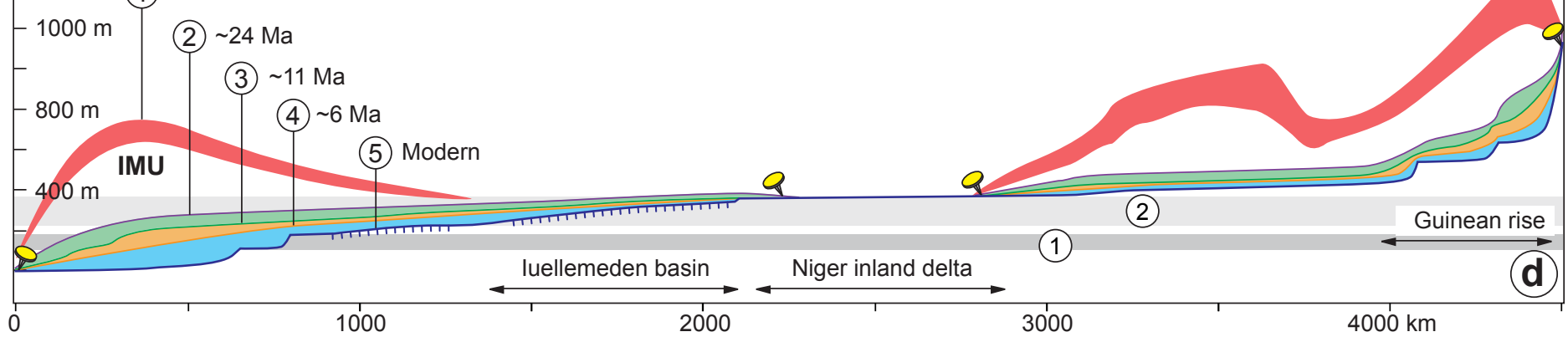

Grimaud et al., Figure 6 
Explanation
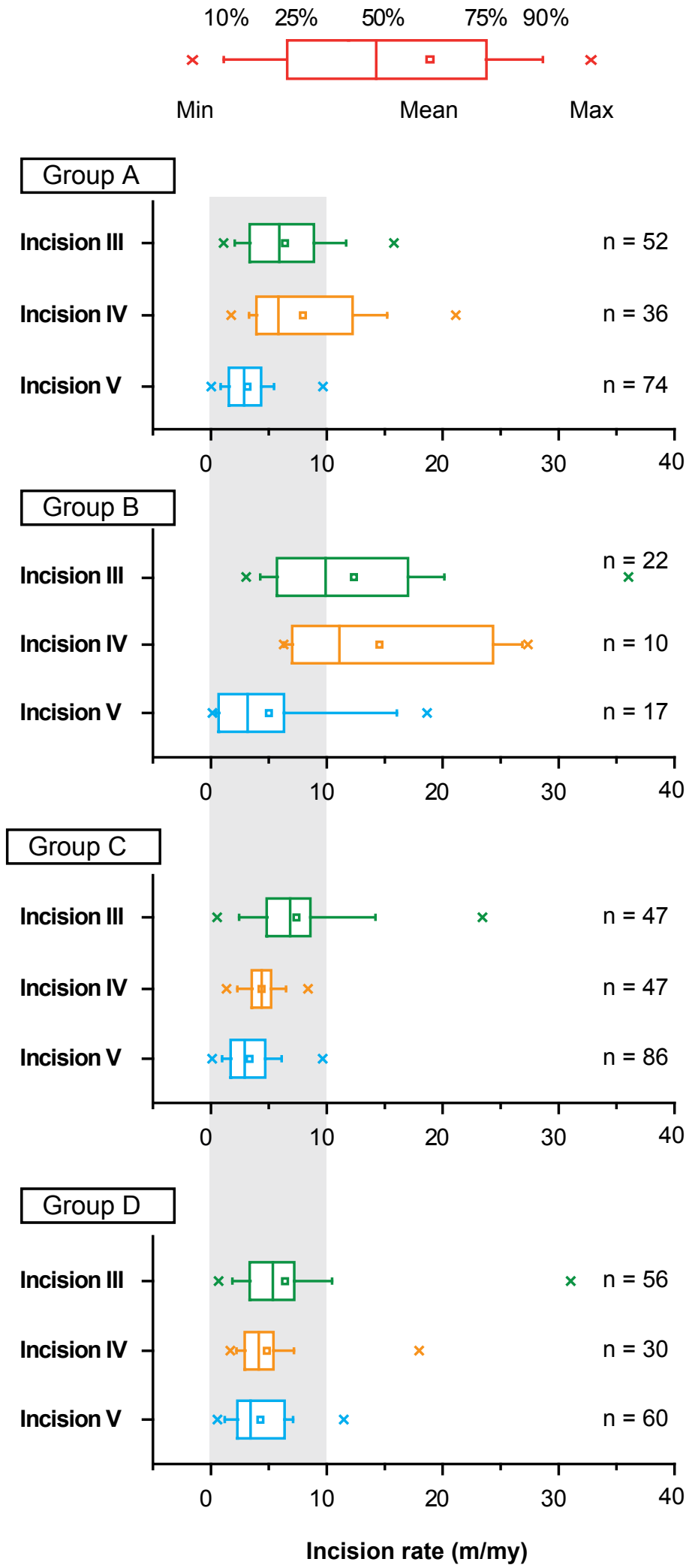

Grimaud et al., Figure 7 
Click here to download Figure: Fig8.pdf

(a) Uniform incision

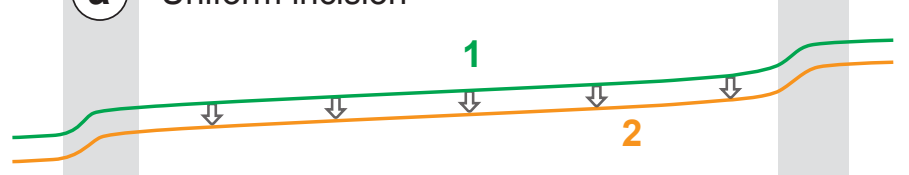

b) Downstream rejuvenation

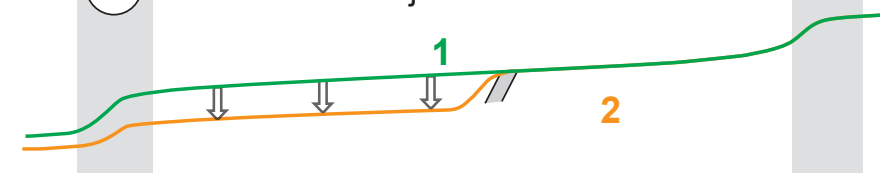

(C) Differential incision

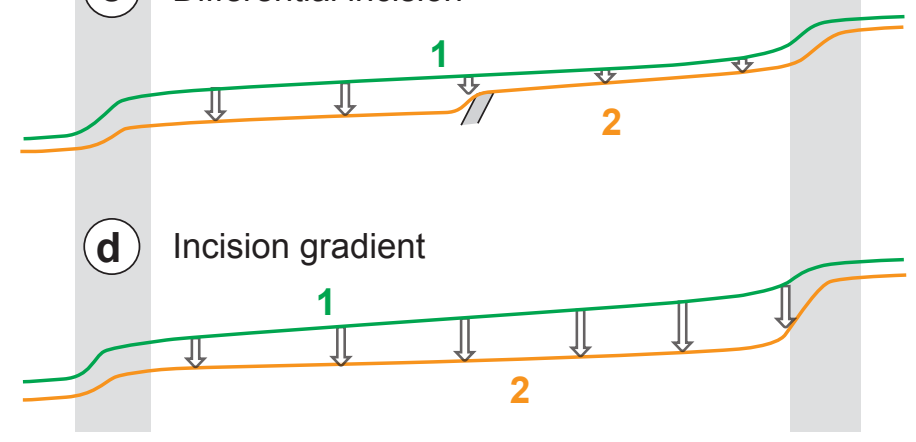

Grimaud et al., Figure 8 


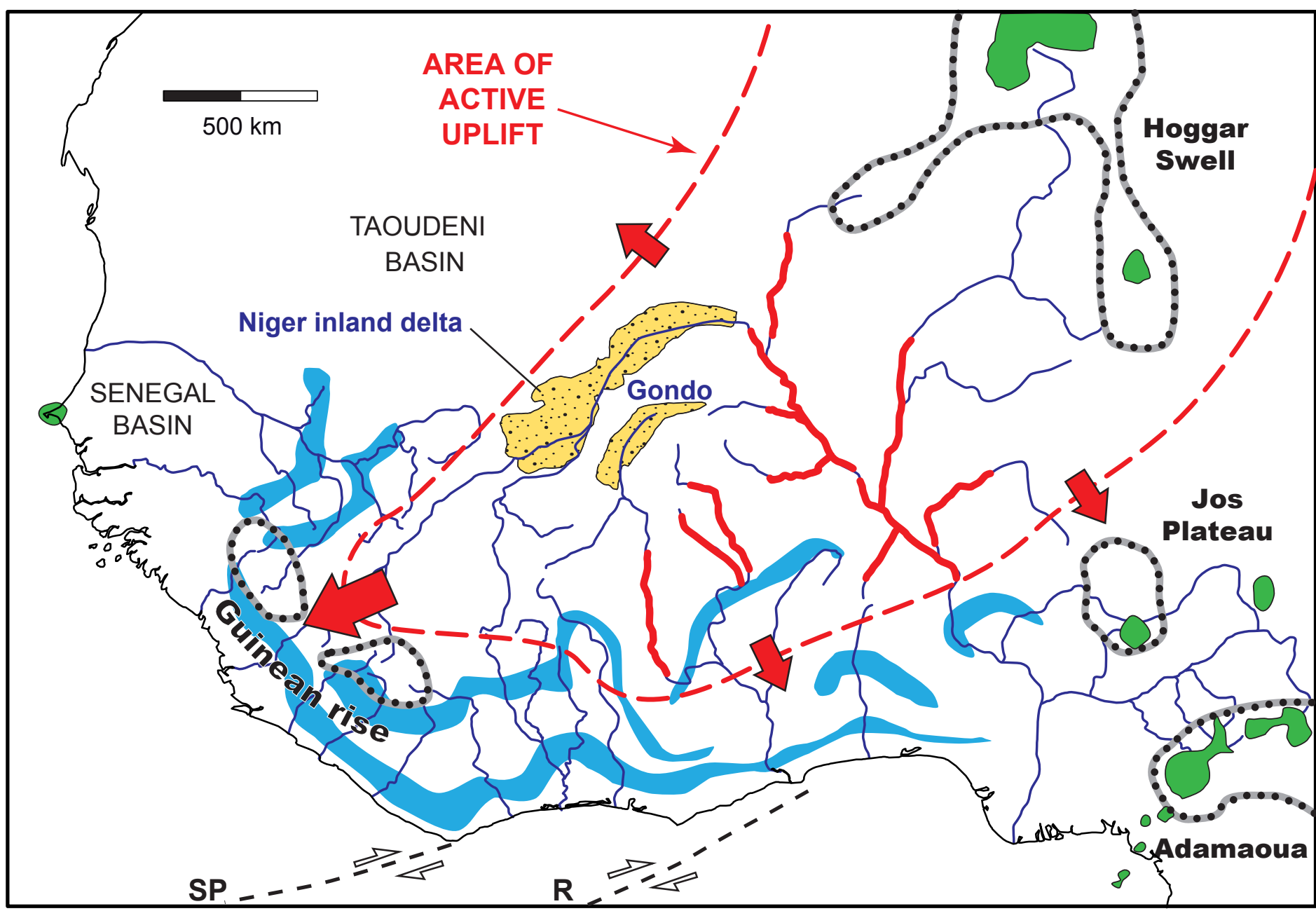

... 650 m contour

Modern knickzones
Cenozoic volcanic provinces

Long wavelength upward-convex river segments

Grimaud et al., Figure 9 

Supplementary material for on-line publication only
Click here to download Supplementary material for on-line publication only: DataRepository.pdf

Supplementary material for on-line publication only
Click here to download Supplementary material for on-line publication only: DataRepository.pdf

.

(

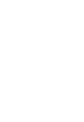
(1) (1) (1) . . . . 列 . 列 列 列 列 .

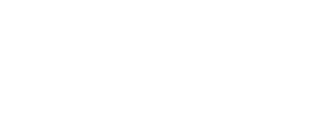

